advantageous for authors, who can then list them among their papers.

Several journals specifically publish negative results. I'm aware of the Journal of Negative Results in Biomedicine, the Journal of Negative Results Ecology and Evolutionary Biology and the psychology Journal of Articles in Support of the Null Hypothesis. There is a forum in the Journal of Universal Computer Sciences for negative results, and PLOS ONE also publishes them. Several other such journals have come and gone; all, I think, are open access.

Even so, negative findings are still a low priority for publication, so we need to find ways to make publishing them more attractive. Bob O'Hara Biodiversity and Climate Research Centre, Frankfurt, Germany. bohara@senckenberg.de

\section{Animal research: a personal lesson}

Had I been a participant in your survey on animal-rights activism (Nature 470, 452-453; 2011), I would have replied that animal extremism once had a negative effect on me - but in an unexpected way.

I worked for many years as a primate researcher studying animal models of abnormal development. Two years after the publication of Peter Singer's Animal Liberation (New York Review/Random House; 1975), my lab was attacked and its rhesus monkeys released. The monkeys were all recaptured and none was seriously injured. I felt intimidated, insulted and furious at what I saw as anti-science stupidity.

My anger was such that I did not give a thought to the possibility that the perpetrators might have been infected with deadly herpes B virus from the monkeys. I failed to alert the emergency departments in the area about this lethal possibility.

For years, my fury blocked the self-reflection that is expected of any scientist who harms vulnerable animals for presumed human benefit.

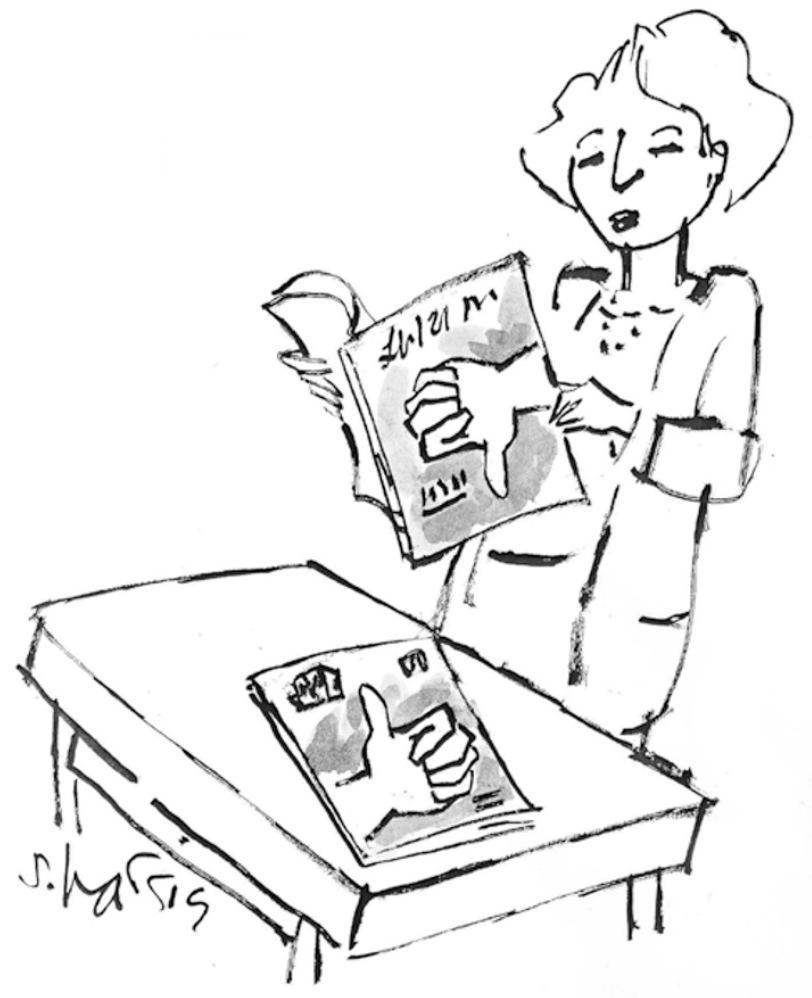

I dismissed even reasonable ethical questions directed at me and my work. Eventually, however, I took up a fellowship at the Kennedy Institute of Ethics at Georgetown University in Washington DC, and at the National Institutes of Health Clinical Center, where I studied bioethics on the moral standing of animals. My intellect and sense of compassionate responsibility broadened; research ethics became my life's focus.

Healthy debate about animal research and the ethical and scientific issues involved must be encouraged, even in the face of hostility. We must also remember that it is unreasonable and inaccurate to label everyone who opposes animal experiments as 'extremists'. John P. Gluck University of New Mexico, Albuquerque, New Mexico, USA.

e-mail:jgluck@unm.edu

\section{Animal research: the peaceful approach}

In your articles on animal activism (www.nature.com/ animalresearch), there was no mention of the many individuals and organizations who work peacefully and legally to educate the public and policy-makers about the ethical and scientific issues surrounding the use of animals in research.

At the American AntiVivisection Society, we seek to bring about meaningful, long-term change for animals in laboratories through the development and use of highquality, non-animal-based teaching, testing and research.

Founded in 1883, the society brings a long-term perspective on opposing views and tactics. Biomedical research lobby groups in the United States have for decades opposed modest improvements to animal welfare laws and convinced researchers that there is too much red tape surrounding animal work. Yet the use of the most common lab animals - rats and mice - remains unregulated in the United States, and there is almost no accountability to the public, even regarding how many of these animals are used.

The same lobby groups attempt to sully the terms 'animal rights' and 'activists' by amplifying the illegal and offensive actions of individuals who do not represent any of us (see, for example, go.nature. com/bxabrm). The reality is that 'peaceful' activists often drive public policy on social issues. This has been true for animal issues for several decades and includes improvements to the US federal Animal Welfare Act.

Crystal Miller-Spiegel American Anti-Vivisection Society, Jenkintown, Pennsylvania, USA. cmillerspiegel@aavs.org

\section{Animal research: replacing the lab rat}

Your coverage of animal research (www.nature.com/ animalresearch) focuses on wellworn themes from proponents, but does offer a way forward.

British biologist Peter Medawar predicted years ago that the use of animals in research would some day be completely replaced by more innovative methods (The Hope of Progress, Methuen; 1972). And Colin Blakemore, an ardent defender of animal research, has repeatedly stated that: "Everyone hopes that a time will come when no animal is used at all." To translate these congruous perspectives into action, we need to develop the kind of proactive strategies that you call for.

The results of your poll (Nature 470, 452-453; 2011) indicate that some scientists might be ready to take this idea forward. Others are clearly not immune to the ethical tensions in animal research. Sadly, most feel that the polarized debate on animal research makes it difficult to express more nuanced views, presumably because they do not want to be perceived as giving ammunition to the extremists.

Medawar's vision to replace animal experimentation is a goal that is worthy of serious effort, for the sake of scientific innovation, ethical responsiveness and animal protection. We should not be deterred by either the scientific challenges or the actions of a handful of extremists. Martin Stephens The Humane Society of the United States, Washington DC, USA. mstephens@hsus.org 